\title{
Covid-19 Enfeksiyonunda Anti-Trombin-3, Protein C ve Protein S Düzeylerinin İncelenmesi
}

\author{
Investigation of Anti-Thrombin-3, \\ Protein C and Protein S Levels in Covid-19 Infection
}

\begin{abstract}
Ahmed Bilal Genç ${ }^{1}$, Selçuk Yaylacı ${ }^{1}$, Hamad Dheir ${ }^{1}$, Tuba Hacıbekiroğlü ${ }^{1}$, Deniz Çekiç ${ }^{1}$, Didar Şenocak ${ }^{1}$, Kubilay İşsever ${ }^{1}$, Gizem Kılıçcıoğlü ${ }^{1}$, Gökhan Oturak ${ }^{2}$, Erdem Çokluk ${ }^{3}$, Ali Tamer ${ }^{1}$, Oğuz Karabay ${ }^{4}$
\end{abstract}

${ }^{1}$ Sakarya Üniversitesi Eğitim ve Araştırma Hastanesi İç hastalıkları A.B.D, Sakarya, Türkiye

${ }^{2}$ Sakarya Üniversitesi Eğitim ve Araştırma Hastanesi Halk Sağllğı A.B.D, Sakarya, Türkiye

${ }^{3}$ Sakarya Üniversitesi Eğitim ve Araştırma Hastanesi Biyokimya A.B.D, Sakarya, Türkiye

${ }^{4}$ Sakarya Üniversitesi Eğitim ve Araştırma Hastanesi Enfeksiyon hastalıkları A.B.D, Sakarya, Türkiye

\author{
Yazıșma Adresi / Correspondence: \\ Deniz Çekiç \\ Şirinevler, Adnan Menderes Cad.Sağllk Sok No:195, 54100 Adapazarı/Sakarya \\ T: :+90 $5517108717 \quad$ E-mail: decekic@gmail.com \\ Geliş Tarihi / Received : 22.12.2020 Kabul Tarihi / Accepted : 31.05.2021
}

Orcid:

\begin{abstract}
Ahmed Bilal Genç https://orcid.org/0000-0002-1607-6355
Selçuk Yaylacı https://orcid.org/0000-0002-6768-7973

Hamad Dheir https://orcid.org/0000-0002-3569-6269

Tuba Hacıbekiroğlu https://orcid.org/0000-0003-1814-5972

Deniz Çekiç https://orcid.org/0000-0002-7114-9334

Didar Şenocak https://orcid.org/0000-0001-9840-9004
\end{abstract}

\begin{abstract}
Kubilay İșsever https://orcid.org/0000-0002-1376-1488 Gizem Kılıçcıoğlu https://orcid.org/0000-0002-3700-4983 Gökhan Oturak https://orcid.org/0000-0003-1608-8433 Erdem Çokluk https://orcid.org/0000-0002-4034-4188

Ali Tamer https://orcid.org/0000-0003-2005-0737

Oğuz Karabay https://orcid.org/0000-0003-1514-1685
\end{abstract}

( Sakarya Tip Dergisi / Sakarya Med J 2021, 11(2):381-387) DOI: 10.31832/smj.845215

\footnotetext{
Öz

Amaç SARS-CoV-2 virüsünün etkeni olduğu COVID-19 enfeksiyonu salgın olușturan önemli bir hastalıktır. COVİD-19 hastalarının birçoğunda kanama ve pıhtılaşma bozukluklarının geliştiği yapılan çalışmalarla gösterilmiştir. Çalışmamızda, ağırlıklı olarak pıhtılaşma eğilimi gözlenen bu hasta grubunda, vücudun doğal antikoagülan proteinleri olan Antitrombin-3 (AT3), protein C (PC) ve protein S (PS) düzeylerinin incelenmesi amaçlandı.

Gereç ve 15 Mart-31 Mayıs tarihleri arasında COVID-19 tanısıyla hastaneye yatıșı yapılan 22 hasta çalıșmaya alındı. Hastaların yașı, cinsiyeti, kronik hastalıkları, servis / yoğun

Yöntem bakım yatıșı, AT3, PC, PS düzeyleri, PT, aPTT, INR, D-Dimer, fibrinojen, rutin laboratuar parametreleri ve mortalite oranları retrospektif olarak değerlendirildi. Bağımsız değişkenler ile yoğun bakım ihtiyacı ve mortalite oranları istatistiksel olarak karşılaștırıldı.

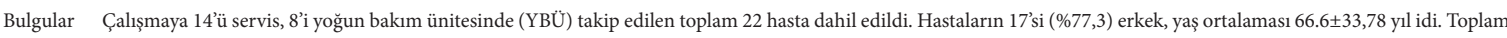
$20(\% 90,9)$ hastanın en az bir kronik hastalığı vardı. Bunların \%36,3 sı Diyabet (DM), \%54,5 ‘ i hipertansiyon idi. Hastalarda nefes darlığı (\%86,3) ve öksürük (\%77,2) en sık görülen șikayetler idi. Takibinde 4 hastada ölüm gerçeklești.

Tartıșma Servis- YBÜ hastaları ve mortal- nonmortal hastalar olarak yapılan iki farklı karşlastırmalar arasında, AT3, PC, PS, düzeyleri arasında istatistiksel olarak anlamlı bir farklılık saptanmadı. Mortal hastalarda nonmortal gruba göre ortalama PTT düzeyleri anlamlı olarak yüksek bulunurken, faktör 9 düzeyleri de YBÜ grubunda servis hastalarına göre anlamlı olarak yüksek tespit edildi.

Sonuç Çalışmamız sonuçlarına göre COVID-19 hastalarında AT3, PC ve PS düzeyleri ile hastalık şiddeti arasında ilişki tespit edilmedi.

Anahtar Anti-trombin 3; Protein C; Protein S; Koagülopati; COVID-19

Kelimeler

Abstract

Objective COVID-19 infection, caused by the SARS-CoV-2 virus, is leaded outbrake all in the world. There are many study showing that; Covid-19 can causes bleeding and coagulation disorders in most patients. In our study: we aim to investigate effect of natural anticoagulation proteins such as Antitrombin-3 (AT3), protein C (PC) and protein S (PS) levels in Covid-19 patientes which suspected disregulated coagulation

Materials

We included 22 patients with Covid-19, followed our clinic between 15 March-31 May. In this Patients; age, gender, chronic disease, need of ward / ICU, AT3, PC, PS, PT, aPTT, INR, D-Dimer, fibrinogen levels, routine laboratory parameters and rate of mortalty retrospectively analyzed Independent variables and intensive care need and mortality rates were compared statistically.

Results A total of 22 patients, 14 of whom were followed up in the ward and 8 in the intensive care unit (ICU), were included in the study. 17 (\%77,3) of patients were male, mean age was $66.6 \pm 33.78$. 20 of 22 patients had chronic diseaes; which was of $\% 36,3$ Diabet (DM), of \%54,5 hpyertension. Most common symptoms was; of (\%86,3) shortness of breath and of (\%77,2) cough spotted. In follow up 4 patients were died.

Conclusion When the compare of needed ward-ICU and mortality-non mortal patients; there is a no significance differences at levels of AT3, PC and PS. In mortal patients PTT levels significiantly higher than non mortal group and Factor 9 levels are significiantly higher than in the ICU patients. Both two parameters were stastisticly significant. Our study showed that in Covid-19 patients AT3, $P C$ ve PS levels were not related with disease severity.

Keywords Antitrombin-3; protein C; protein S; coagulopathy; COVID-19
} 


\section{GIIRIŞ}

COVID-19 tüm dünya nüfusunu etkilen ve yüksek mortalite oranlarına sahip salgın bir hastalıktır. Mortalite üzerine yaş, kronik hastalıklar, cinsiyet ve bazı laboratuvar parametrelerinin etkisi olduğu bildirilmiştir. ${ }^{1,2}$ Pıhtılaşma sistemindeki bozuklukların yüksek mortalite riski ile ilişkili bir diğer parametre olabileceği yapılan çalışmalarda gösterilmiştir. ${ }^{3-5}$ Özellikle bakteriyel enfeksiyonlar başta olmak üzere, birçok enfeksiyonda gerek damar hasarı gerekse inflamatuar sitokinlerin etkisi ile salınan doku faktörünün koagülasyon sistemini tetiklemesi sonucu hiperkoagülasyon gerçekleştiği bilinmektedir. Bunun sonucunda ise yaygın damar içi pıhtılaşma (DİC) klinik tablosu oluşmaktadır. COVID-19 hastalarında yapılan klinik çalışmalarda daha çok ılımlı bir DİC tablosu ve buna eşlik eden trombotik mikroanjiyopatinin geliştiği gözlemlenmiştir. ${ }^{6}$ Özellikle kritik düzey COVİD-19 hastalarında koagülasyon bozukluğu sonucu gelişen trombotik komplikasyonların daha ciddi ve sık görüldüğü gözlemlenmiştir. Aynı çalışmalarda D-Dimer ve fibrin yıkım ürünleri yüksek olan hastalarda COVID-19 pnömonisi ile ilişkili mortalite oranları $11.4 \%$ olarak bildirilmiş ve sepsis koagülopati skoru yüksek olan şiddetli COVID-19 pnömonisi geçiren hastalarda antikoagülan tedavinin mortalite riskini azaltt1ğ1 gösterilmiştir. ${ }^{3,4}$ Anti-trombin 3 (AT3), protein C (PC), protein S (PS) vücudun doğal antikoagülan proteinleridir. Pıhtılaşma eğiliminin arttığı gösterilen COVID-19 hastalarında vücudun doğal antikoagülanlarının nasıl bir cevap verdiği araştırılan bir konudur. COVID-19 pnömonisi olan hastalarda AT3'ün hafif düştüğü, PC'nin arttığı ve PS seviyelerinin belirgin azaldığını bildirilmektedir. ${ }^{7}$

Biz çalışmamızda hastalık ciddiyet seviyeleri farklı COVID-19 hastalarında AT3, PC, PS ve diğer pıhtılaşma parametrelerini değerlendirerek bu biyokimyasal parametrelerin hastalık şiddeti ve mortalite üzerine etkilerini incelemeyi amaçladık.

\section{GEREÇ VE YÖNTEMLER}

\section{Hasta popülasyonu}

Çalışmamız Sakarya Üniversitesi Tip Fakültesi Etik Kurulu Evrak Tarih ve Sayısı: 27/04/2020-E.4267 izni ile yapılmıştır. Çalışmamız retrospektif kesitsel tanımlayıcı bir çalışma olup hastaların tedavisi gibi konularda müdahil olunmamıştır. Çalışmaya Sakarya üniversitesi Eğitim ve Araştırma Hastanesinde 15 Mart-31 Mayıs 2020 tarihleri arasında COVID-19 tanısıyla hastaneye yatışı yapılan, nazofarengeal sürüntü örneği PCR pozitif, 18-90 yaş arası toplam 22 hasta dahil edildi. Genel durum bozukluğu, taşipne (solunum sayısı > 30), saturasyon düşüklüğü (So2<93), şok, organ yetmezliği gibi nedenlerle yoğun bakımda takip edilen kritik düzey 8 hasta ile servis şartlarında takip edilen, kritik düzey olmayan 14 hasta retrospektif olarak değerlendirildi. Kanser ve bilinen hematolojik hastalığı olan hastalar ile başvuru anında AT3, PC ve PS düzeylerini etkileyebilecek ilaç kullanım öyküsü olan hastalar çalışmaya alınmadı. Hastaların yaş, cinsiyet, kronik hastalıklar, servis-yoğun bakım yatışı, yatış günü ve kullandıkları ilaçlar ve verilen tüm tedaviler otomasyon sistemi üzerinden kaydedildi. Hastaların 1-3. günler, 5-7. günler ve taburculuk-exitus günlerinde çalışılan lökosit (WBC-White blood cell), hemoglobin ( $\mathrm{Hb}$ ), hematokrit (Hct), lenfosit, nötrofil, trombosit (PLT-platelet), protrombin zamanı (PT), parsiyel tromboplastin zamanı (PTT), Internationel Normalized Ratio (INR), D-Dimer, ferritin, albümin (Alb), laktat dehidrogenaz (LDH), C reaktif protein (CRP), prokalsitonin, fibrinojen değerleri otomasyon sisteminden kaydedilerek aritmetik ortalaması hesaplandı ve ortalama değer olarak verildi. Yatışının 1. gününde bakılan üre, kreatinin, sodyum $(\mathrm{Na})$, potasyum $(\mathrm{K})$, kalsiyum $(\mathrm{Ca})$, fosfor $(\mathrm{P})$, magnezyum (Mg), ALT alanin amino transferaz (ALT), aspartat amino transferaz (AST), protein $\mathrm{C}(\mathrm{PC})$, protein S (PS), anti-trombin 3 (AT3), sedimentasyon, miyoglobin değerleri yine otomasyon sisteminden alınarak kaydedildi. Nötrofil ve lenfosit düzeylerinden Nötrofil lenfosit oranı (NLO) hesaplandı. Sağ kalan ve ölen hastalar arasında kaydedilen bu parametrelerin ilişkileri, etkileri istatistiksel yöntemler ile analiz edildi. 
Serum Na ve K düzeyi Ion Selective Electrode (ISE) yöntemiyle çalışılırken, albümin, $\mathrm{LDH}$, üre, kreatinin, Ca, P, $\mathrm{Mg}$, ALT, AST düzeyleri spektrofotometrik, CRP düzeyi immünotürbidimetrik yöntemle Olympus AU5800 (Beckman Coulter, Inc. Brea, CA92821 USA) otoanalizör ile ölçüldü. Ferritin düzeyi ABBOTT ARCHITECT I2000SR (Abbott Laboratories) cihazında kemilüminesans yöntemle, tam kan sayımı CELL-DYN 3700 CD-3700SL (Abbott Diagnostics Divisıon, Abbott Laboratories) cihazında laser ölçüm ve LED Flow Cell yöntemiyle; PT, aPTT ve fibrinojen optik metotla, Faktör 8 ve 9 kromojenik yöntem kullanılarak Diagon CoagXL (Budapest, Hungary) cihazında çalışıldı. AT3, PC ve PS seviyeleri Tokra Amax 200 (Türkiye) cihazında kromojenik yöntemle, Sedimantasyon ölçümü Vacuplus ESR-20 (Türkiye) tam otomatik ESR analizöründe, prokalsitonin Roch eCobas e 411 (Hitachi, 6544-01 Tokyo Japan) türbidimetrik yöntemle çalışıldı.

Çalışmanın yapılması için Sakarya Üniversitesi Tıp Fakültesi Etik Kurulundan onam alındı. Dünya Tıp Birliği (WMA) Helsinki Bildirgesine uyulmuştur.

\section{İstatistiksel Analiz}

Nicel değerler için ortalama değer ve standart sapma kullanılmıştır. Nitel değerler ise sayı ve yüzde olarak verilmiştir. Normallik testi için Shapiro-Wilk kullanılmıştır. Nicel değerlerin kıyaslanması için ise Ki-kare testi kullanılmıştır. Normallik dağılımına göre nicel değerler için Mann-Whitney $\mathrm{U}$ ve $\mathrm{T}$ testi kullanılmıştır. İstatistiksel anlamlılık için $\mathrm{p}<0,05$ olarak kabul edilmiştir. SPSS v20.0 (IBM SPSS Statistics for Windows, Version 20.0; Armonk, NY, USA) paket programı istatistiksel analiz için kullanılmıştır.

\section{BULGULAR}

Çalışmaya dahil edilen 22 hastanın $17(\% 77,3)$ 'si erkek ve yaş ortalaması $66.6 \pm 33,78$ yıl idi. $20(\% 90,9)$ hastada en az bir kronik hastalık vardı. Kronik hastalıkların \%36,3 sı Diyabetes Mellitus (DM), \%54,5 i hipertansiyon idi (Tablo 1). Kronik hastalıkları nedeniyle hastaların $8(\% 36,3)$ 'i ACE (anjiyotensin converting enzim) inhibitörü, 4 (\%18,1)'ü
ARB (anjiyotensin reseptör blokörü), 6 (\%27,2)'s1 metformin, 2 (\%9.09)'si diğer oral anti diyabetiklerden, 2 (\%9.09)'si ASA (asetil salisilik asit) kullanıyordu. Hastalarda görülen en sık semptomlar; nefes darlığ $1 \% 86,3)$ ve öksürük $(\% 77,2)$ idi. Hastaların tamamına COVID-19 için klorokin ve oseltamivir tedavisi verilirken, $21(\% 95,4)$ 'ine azitromisin, $20(\% 90,9)$ 'sine favipiravir tedavisi uygulandı. Servis şartlarında $14(\% 63,6)$, yoğun bakım ünitesinde (YBÜ) $8(\% 36,4)$ hasta tedavi edilirken, toplam $4(\% 18,2)$ hastada ölüm gözlendi (Tablo 1).

\begin{tabular}{|c|c|}
\hline \multicolumn{2}{|c|}{$\begin{array}{l}\text { Tablo 1. Hastaların yaş,cinsiyet, komorbit durumları ve tedavileri ile ilgili } \\
\text { demografik veriler }\end{array}$} \\
\hline Parameters & Değerler \\
\hline $\begin{array}{l}\text { Yaș (yıl) Ortalama } \pm \text { SS } \\
\text { (min.-med.-maks.) }\end{array}$ & $\begin{array}{c}66.63 \pm 33.6 \\
(25.0-69.5-86.0)\end{array}$ \\
\hline Cinsiyet (E/K) n (\%) & $17 / 5(77.3 / 32.7)$ \\
\hline Kronik Hastalık n (\%) & $20(90.9)$ \\
\hline DM & $8(36.3)$ \\
\hline HT & $12(54.5)$ \\
\hline КАН & $2(9.09)$ \\
\hline KKY & $2(9.09)$ \\
\hline KBY & $1(4.54)$ \\
\hline Nörolojik Hastalık & $1(4.54)$ \\
\hline \multicolumn{2}{|l|}{ İlaçlar n (\%) } \\
\hline ACE inhibitörüi & $8(36.3)$ \\
\hline ARB & $4(18.1)$ \\
\hline ASA & $2(9.09)$ \\
\hline Metformin & $6(27.2)$ \\
\hline Diğer OAD & $2(9.09)$ \\
\hline \multicolumn{2}{|l|}{ Şikayetler n (\%) } \\
\hline Öksürükk & $17(77.2)$ \\
\hline Nefes Darlığı & $19(86.3)$ \\
\hline Baş Ağrısı & $1(4.54)$ \\
\hline \multicolumn{2}{|l|}{ Verilen tedavi n (\%) } \\
\hline Klorokin & $22(100)$ \\
\hline Oseltamivir & $22(100)$ \\
\hline Favipiravir & $20(90.9)$ \\
\hline Steroid & $0(0)$ \\
\hline Azitro & $21(95.4)$ \\
\hline İVİG & $0(0)$ \\
\hline Plazma & $0(0)$ \\
\hline HDF & $0(0)$ \\
\hline
\end{tabular}


Sakarya Tip Dergisi 2021;11(2):381-387

GENÇ ve Ark., Covid-19'da Tromboz Belirteçlerinin Değerlendirilmesi

Hastaları servis ve YBÜ hastaları olarak iki gruba ayırarak yapılan analizde; YBÜ hastalarında Faktör 9 ( $\mathrm{p}=0.029)$, ortalama prokalsitonin (PCT) $(\mathrm{p}=0.021)$ ve nötrofil lenfosit oranı $(\mathrm{NLO})(\mathrm{p}=0.05)$ anlamlı olarak yüksek bulundu. Ortalama lenfosit düzeyi ise YBÜ hastalarında anlamlı olarak düşük bulundu $(\mathrm{p}=0.02)$. Servis ve YBÜ hastaları arasında
WBC, nötrofil, trombosit ortalama düzeyleri, tam kan sayımı alt parametreleri, biyokimya parametreleri, AT3, PC, PS, Faktör 8 düzeyleri arasında istatistiksel olarak anlamlı bir farklılık saptanmadı. D-DİMER düzeyleri ise istatistiksel anlamlı olmasa da YBÜ hastalarında daha yüksek düzeylerde tespit edildi (Tablo 2).

\begin{tabular}{|c|c|c|c|}
\hline Parameters & $\begin{array}{l}\text { Servis (n:14) } \\
\text { ort } \pm \text { ss }\end{array}$ & $\begin{array}{l}\text { Yoğun Bakım (n:8) } \\
\text { ort } \pm \text { ss }\end{array}$ & $\mathrm{p}$ \\
\hline Ortalama Hemoglobin $(\mathrm{g} / \mathrm{dL})$ & $14,5 \pm 15$ & $11,8 \pm 1.8$ & 0,188 \\
\hline Ortalama Hemotokrit (\%) & $38,9 \pm 8,9$ & $36,6 \pm 6,6$ & 0,219 \\
\hline Ortalama PLT $(\mathrm{K} / \mathrm{uL})$ & $232,2 \pm 151$ & $242,9 \pm 154$ & 0,754 \\
\hline Ortalama WBC (K/uL) & $7,38 \pm 3,7$ & $9,26 \pm 7,4$ & 0,267 \\
\hline Ortalama NLR & $3,96 \pm 3,5$ & $10,86 \pm 18,8$ & $0,05^{*}$ \\
\hline Ortalama nötrofil (K/u L) & $5,23 \pm 3,4$ & $7,75 \pm 7,8$ & 0,07 \\
\hline Ortalama lenfosit (K/u L) & $1,44 \pm 0,92$ & $0,99 \pm 0,96$ & $0,04^{*}$ \\
\hline Ortalama- D-dimer (Ug/FEu) & $1340 \pm 2482$ & $2389 \pm 4504$ & 0,059 \\
\hline Ortalama-a PTT (sn) & $27,6 \pm 9,4$ & $30,5 \pm 22,3$ & 0,616 \\
\hline Ortalama- PT (sn) & $17 \pm 26,4$ & $15,6 \pm 8,8$ & 0,525 \\
\hline Ortalama INR & $1,6 \pm 2,6$ & $1,4 \pm 0,5$ & 0,525 \\
\hline Protein C (\%) & $70,3 \pm 15$ & $68,62 \pm 12,2$ & 0,920 \\
\hline Protein S (\%) & $69,7 \pm 7,74$ & $71,6 \pm 12,3$ & 0,868 \\
\hline VWF (\%) & $209,5 \pm 234$ & $311,9 \pm 312$ & 0,583 \\
\hline Antitrombin 3 (\%) & $66,07 \pm 16,9$ & $64,5 \pm 14,6$ & 0,522 \\
\hline Faktör 8 (\%) & $56,8 \pm 136$ & $144,3 \pm 240$ & 0,060 \\
\hline Faktör 9 (\%) & $37,1 \pm 68$ & $100,2 \pm 124$ & $0,029^{*}$ \\
\hline Ortalama fibrinojen $(\mathrm{mg} / \mathrm{dL})$ & $412,1 \pm 108$ & $383,4 \pm 114$ & 0,258 \\
\hline Ortalama CRP (mg/L) & $56,3 \pm 72$ & $88,4 \pm 118$ & 0,127 \\
\hline Ortalama Ferritin (ug/L) & $699 \pm 1658$ & $1052 \pm 2274$ & 0,482 \\
\hline Ortalama Albumin (g/L) & $31,2 \pm 7,2$ & $28,5 \pm 6,92$ & 0,107 \\
\hline Ortalama LDH (U/L) & $354,8 \pm 240$ & $388 \pm 169$ & 0,497 \\
\hline Ortalama Prokalsitonin $(\mathrm{ng} / \mathrm{mL})$ & $0,19 \pm 0,34$ & $0,45 \pm 0,64$ & $0,021^{*}$ \\
\hline Ortalama Miyoglobin (ug/L) & $82,01 \pm 98$ & $190,7 \pm 308$ & 0,095 \\
\hline Üre (mg/dL) & $56,7 \pm 51$ & $65,5 \pm 59$ & 0,570 \\
\hline Kreatinin $(\mathrm{mg} / \mathrm{dL})$ & $1,03 \pm 1,1$ & $0,88 \pm 1$ & 0,188 \\
\hline $\mathrm{Na}(\mathrm{mmol} / \mathrm{L})$ & $132 \pm 5,4$ & $133,6 \pm 13$ & 0,522 \\
\hline $\mathbf{K}(\mathrm{mmol} / \mathrm{L})$ & $4,09 \pm 1.08$ & $4,2 \pm 0,88$ & 0,496 \\
\hline $\mathrm{Ca}(\mathrm{mg} / \mathrm{dL})$ & $8,64 \pm 1.02$ & $8,8 \pm 1,5$ & 0,510 \\
\hline $\mathbf{P}(\mathrm{mg} / \mathrm{dL})$ & $3,5 \pm 1,2$ & $3,5 \pm 1,6$ & 0,976 \\
\hline $\mathbf{M g}(\mathrm{mg} / \mathrm{dL})$ & $2,9 \pm 1,6$ & $2,64 \pm 1,1$ & 0,410 \\
\hline $\operatorname{ALT}(\mathrm{U} / \mathrm{L})$ & $40,5 \pm 76$ & $40,1 \pm 56$ & 0,482 \\
\hline $\operatorname{AST}(\mathrm{U} / \mathrm{L})$ & $49,9 \pm 72$ & $37,1 \pm 44$ & 0,525 \\
\hline Sedimentasyon $(\mathrm{mm} / \mathrm{s})$ & $56,7 \pm 51$ & $65,5 \pm 59$ & 0,476 \\
\hline
\end{tabular}


Hastaları mortal ve non-mortal hastalar olarak gruplandırdığımızda; mortal grupta ortalama nötrofil ( $\mathrm{p}=0.042)$, NLR $(\mathrm{p}=0.008)$, CRP $(\mathrm{p}=0.033)$, PCT $(\mathrm{p}=0.00)$ ve aPTT $(\mathrm{p}=0.012)$ nonmortal gruba göre istatistiksel olarak anlamlı yüksek bulundu. Lenfosit sayısı mortal grupta anlamlı olarak daha düşüktü ( $\mathrm{p}=0.002)$. WBC, PLT, diğer tam kan sayımı alt parametreleri ile biyokimya ve koagülasyon parametreleri, AT 3, PC, PS, Faktör 8 düzeyleri açısından istatistiksel olarak anlamlı fark saptanmadı (Tablo 3).

\begin{tabular}{|c|c|c|c|}
\hline Parameters & $\begin{array}{l}\text { Mortal (n:4) } \\
\text { ort } \pm s s\end{array}$ & $\begin{array}{l}\text { Nonmortal (n:18) } \\
\text { ort } \pm \mathrm{ss}\end{array}$ & $\mathbf{p}$ \\
\hline Hemoglobin & $11,2 \pm 2$ & $14,0 \pm 13$ & 0,081 \\
\hline Ortalama Hemoglobin (g/dL) & $33,9 \pm 4,5$ & $39 \pm 7,8$ & $0,024^{*}$ \\
\hline Ortalama Hemotokrit (\%) & $241,8 \pm 174$ & $234,8 \pm 148$ & 0,870 \\
\hline Ortalama PLT $(\mathrm{K} / \mathrm{uL})$ & $11,5 \pm 8,5$ & $7,3 \pm 3,2$ & 0,098 \\
\hline Ortalama WBC (K/uL) & $17,5 \pm 18,4$ & $4,01 \pm 3,4$ & $0,001^{*}$ \\
\hline Ortalama NLR & $10,31 \pm 8,76$ & $5,22 \pm 3$ & 0,042 \\
\hline Ortalama nötrofil (K/u L) & $0,616 \pm 0,18$ & $1,42 \pm 0,86$ & $0,002^{*}$ \\
\hline Ortalama lenfosit $(\mathrm{K} / \mathrm{u} \mathrm{L})$ & $1745 \pm 1222$ & $1716 \pm 3700$ & 0,262 \\
\hline Ortalama- D-dimer (Ug/FEu) & $36,12 \pm 28$ & $27,02 \pm 8,9$ & $0,033^{*}$ \\
\hline Ortalama-a PTT (sn) & $16,48 \pm 12$ & $16,6 \pm 23,2$ & 0,712 \\
\hline Ortalama- PT(sn) & $1,41 \pm 0,7$ & $1,56 \pm 2,34$ & 0,712 \\
\hline Ortalama INR & $69 \pm 16,5$ & $69,8 \pm 14,2$ & 0,652 \\
\hline Protein c (\%) & $71 \pm 18$ & $70,3 \pm 13,8$ & 0,774 \\
\hline Protein S(\%) & $281,7 \pm 230$ & $239,1 \pm 300$ & 0,611 \\
\hline VWF (\%) & $67 \pm 10.1$ & $65,1 \pm 16,9$ & 0,149 \\
\hline Antitrombin 3 (\%) & $106,5 \pm 198$ & $80,7 \pm 199$ & 0,304 \\
\hline Faktör 8 (\%) & $87,1 \pm 125$ & $48,8 \pm 99$ & 0,142 \\
\hline Faktör 9 (\%) & $367,2 \pm 122$ & $409 \pm 107$ & 0,766 \\
\hline Ortalama fibrinojen $(\mathrm{mg} / \mathrm{dL})$ & $117,8 \pm 144$ & $56,9 \pm 66,4$ & $0,008^{*}$ \\
\hline Ortalama CRP $(\mathrm{mg} / \mathrm{L})$ & $1593 \pm 2812$ & $657 \pm 1520$ & 0,141 \\
\hline Ortalama Ferritin (ug/L) & $26,5 \pm 7,2$ & $31,05 \pm 6,72$ & $0,026^{*}$ \\
\hline Ortalama Albumin $(\mathrm{g} / \mathrm{L})$ & $406,1 \pm 242$ & $358 \pm 212$ & 0,438 \\
\hline Ortalama LDH (U/L) & $0,69 \pm 0,54$ & $0,19 \pm 0,30$ & $0,000^{*}$ \\
\hline Ortalama Prokalsitonin ( $\mathrm{ng} / \mathrm{mL})$ & $270,8 \pm 352$ & $88,3 \pm 116$ & 0,053 \\
\hline Ortalama Miyoglobin (ug/L) & $73,7 \pm 151$ & $40,6 \pm 33$ & 0,712 \\
\hline Üre (mg/dL) & $0,98 \pm 1,48$ & $0,98 \pm 1,06$ & 0,342 \\
\hline Kreatinin (mg/dL) & $129,5 \pm 7,6$ & $133,5 \pm 8,9$ & 0,081 \\
\hline $\mathrm{Na}(\mathrm{mmol} / \mathrm{L})$ & $4,32 \pm 1,2$ & $4,1 \pm 0,96$ & 0,457 \\
\hline $\mathbf{K}(\mathrm{mmol} / \mathrm{L})$ & $8,45 \pm 0,9$ & $8,76 \pm 1,2$ & 0,356 \\
\hline $\mathrm{Ca}(\mathrm{mg} / \mathrm{dL})$ & $3,7 \pm 2$ & $3,5 \pm 1,2$ & 0,711 \\
\hline $\mathbf{P}(\mathrm{mg} / \mathrm{dL})$ & $2,7 \pm 1,26$ & $2,87 \pm 1,5$ & 0,692 \\
\hline $\mathbf{M g}(\mathrm{mg} / \mathrm{dL})$ & $46,2 \pm 78$ & $39 \pm 67$ & 0,712 \\
\hline $\operatorname{ALT}(\mathrm{U} / \mathrm{L})$ & $47,2 \pm 56$ & $44,8 \pm 68$ & 0,484 \\
\hline $\operatorname{AST}(\mathrm{U} / \mathrm{L})$ & $72,2 \pm 52$ & $57,1 \pm 54$ & 0,324 \\
\hline Sedimentasyon $(\mathrm{mm} / \mathrm{s})$ & & & \\
\hline
\end{tabular}




\section{TARTIŞMA}

SARS-CoV2 virüsünün oluşturduğu COVİD-19 hastalığ1 ağırlıklı olarak solunum yolu enfeksiyonu ile karşımıza çıkmaktadır. Bazı hastalarda hastanın verdiği immun yanıt şiddetine bağlı olarak hastalık seyri kötüleşerek ARDS, şok, multiorgan yetmezliği, ölüm gibi ciddi ve sistemik bir klinik tablo gelişebilmektedir. Ciddi hasta grubunda en önemli ölüm nedenlerinden biri; DİC ve trombotik mikroanjiyopati tablosunun kombinasyonu şeklinde görülen bir koagülasyon artışıdır. COVİD-19 da görülen koagülasyon bozukluğunun klasik DİC tablosundan farkı; DİC de görülen trombositopeniden çok daha ılımlı bir trombositopeni gelişmesi, 1lımlı D-DİMER düzeylerinin aksine çok yüksek düzeyde D-DİMER düzeylerine sahip olması ve daha ılımlı bir protrombin zamanı uzamasının görülmesidir. ${ }^{8}$ Yüksek D-DİMER düzeyi birçok çalışmada gösterilmiş tipik bir COVİD-19 bulgusu haline gelmiştir.9 Ölüm görülen hastalarda D-DİMER düzeyinin yaşayan hastalara göre 3-4 kat daha yüksek olduğu ve çalışmamızla uyumlu olarak kritik düzey hasta grubu olan YBÜ hastalarında D-DİMER düzeylerinin servis hastalarına göre çok daha fazla artmış olduğu gösterilmiştir. ${ }^{10,11}$ Farklı bir çalışmada D-DİMER düzeyinin dört kat artışı, Covid-19 hastalarında hastane içi mortalite ile ilişkilendirilmiş. ${ }^{12}$ Çalışmamızda YBÜ hastalarında ortalama D-Dimer düzeyleri istatistiksel olarak anlamlı olmamakla birlikte yüksek tespit edildi fakat mortalite grubunda bir farklılık saptanmadı.

Protrombin zamanı ve aPTT uzama, antitrombin düzeylerinde düşüklük literarürde gösterilmiş diğer koagülopati bulgularıdır. Özellikle kritik düzey yoğun bakım hastalarında PT ve aPTT uzaması net bir şekilde gösterilmiştir. ${ }^{3}$

COVID-19 pnömonisi olan hastalarda antitrombin-3 hafif düştüğü, protein $C$ arttığ 1 ve protein S seviyelerinde belirgin azalma ve faktör 8 de ciddi yükselme olduğu gösterilmiş. ${ }^{7,13}$ Çalışmamızda mortalite grubunda ortalama PTT anlamlı yüksek, faktör 9 düzeyi yoğun bakım grubunda anlamlı yüksek iken; mortal grupta yüksek olmasına rağmen anlamlı ilişki tespit edilmedi.
COVİD-19 hastalarında CRP, prokalsitonin, lökosit, nötrofil gibi inflamatuvar belirteçlerin arttığı, özellikle artmış nötrofil, azalmış lenfosit düzeylerine bağlı olarak artmış nötrofil/lenfosit (NLO) oranının hastalık şiddeti ile ilişkisi gösterilmiştir. ${ }^{14}$ Diğer bir çalışmada kritik düzey COVİD-19 hastalarının \%80 ninde ciddi lenfopeni olduğu tesbit edilmiştir. ${ }^{15} 21$ çalışmanın yapıldığı metaanalizde ise 3377 kişilik hasta grubunda lenfosit düzeyleri istatistiksel olarak ciddi hasta grubunda düşük bulunmuştur. ${ }^{16}$ Çalışmamızda YBÜ hastalarında ve ölen hastalarda nötrofil lenfosit oranı (NLO) ve prokalsitonin düzeyleri istatistiksel olarak anlamlı yüksek bulunurken lenfosit düzeyleri düşük tespit edildi. Bu bulgular literatürde bildirilen COVID-19 ile ilişkili genel laboratuvar bulguları ile uyumlu idi.

Literatürde trombositopeninin kötü prognoz ve mortalite ilişkisi olduğu çeşitli çalışmalarda gösterilmiştir. ${ }^{17-18}$ Ancak çalışmamızda mortalite grubunda ve yoğun bakım grubunda trombosit düzeylerinde anlamlı farklılık tespit edilmedi.

\section{SONUÇ}

Çalışmamızda, literatürle uyumlu şekilde CRP, prokalsitonin, nötrofil, PTT, DDimer yüksekliği ve albümin, lenfosit düşüklügü kötü prognostik faktörler olarak değerlendirilebilir. AT 3, protein C, protein S düzeyleri yoğun bakım yatışı ve hastalık şiddeti arasında ilişki tespit edilemedi. Faktör 8 ve 9 yoğun bakım grubunda anlamlı yüksek iken mortalite ile ilişkili tespit edilmedi.

\section{Kisitlilık}

Çalışmamızın tek merkezli olması ve vaka sayısının düşüklüğü olarak gösterilebilir.

Çalışmamız Sakarya Üniversitesi Tıp Fakültesi Etik Kurulu Evrak Tarih ve Sayısı: 27/04/2020-E.4267 izni ile yapılmıştır. 
Sakarya Tip Dergisi 2021;11(2):381-387

GENÇ ve Ark., Covid-19'da Tromboz Belirteçlerinin Değerlendirilmesi

\section{Kaynaklar}

1. Li X, Xu S, Yu M, Wang K, Tao Y, Zhou Y, et al. Risk factors for severity and mortality in adult COVID-19 inpatients in Wuhan. J Allergy Clin Immunol 2020. https://doi.org/10.1016/j.jaci.2020.04.006.

2. Zhou F, Yu T, Du R, Fan G, Liu Y, Liu Z, et al. Clinical course and risk factors for mortality of adult inpatients with COVID-19 in Wuhan, China: a retrospective cohort study. Lancet 2020;395:1054-62.

3. Tang N, Li D, Wang X, Sun Z. Abnormal coagulation parameters are associated with poor prognosis in patients with novel coronavirus pneumonia. J Thromb Haemost 2020;18:844-7.

4. Tang N, Bai H, Chen X, Gong J, Li D, Sun Z. Anticoagulant treatment is associated with decreased mortality in severe coronavirus disease 2019 patients with coagulopathy. J Thromb Haemost 2020;18:1094-9.

5. Terpos E, Ntanasis-Stathopoulos I, Elalamy I, Kastritis E, Sergentanis TN, Politou M, et al. Hematological findings and complications of COVID-19. Am J Hematol 2020. https://doi. org/10.1002/ajh.25829.

6. Levi M, Thachil J, Iba T, Levy JH. Coagulation abnormalities and thrombosis in patients with COVID-19. Lancet Haematol 2020;7(6):e438-e440. doi:10.1016/S2352-3026(20)30145-9)

7. Panigada M, Bottino N, Tagliabue P, Grasselli G, Novembrino C, Chantarangkul V, et al. Hypercoagulability of COVID-19 patients in Intensive Care Unit. A Report of Thromboelastography Findings and other Parameters of Hemostasis. J Thromb Haemost 2020. https:// doi.org/10.1111/jth.14850.

8. Levi M, Scully M. How I treat disseminated intravascular coagulation. Blood 2018; 131: $845-54$.

9. Guan WJ, Ni ZY, Hu Y, et al. Clinical characteristics of coronavirus disease 2019 in China. N Engl J Med 2020; 382: 1708-20
10. Tang N, Li D, Wang X, Sun Z. Abnormal coagulation parameters are associated with poor prognosis in patients with novel coronavirus pneumonia. J Thromb Haemost 2020; 18: 844-47.,

11. Huang C, Wang Y, Li X, et al. Clinical features of patients infected with 2019 novel coronavirus in Wuhan, China. Lancet 2020; 395: 497-50.

12. Zhang L, Yan X, Fan Q, Liu H, Liu X, Liu Z, et al. D-dimer levels on admission to predict in-hospital mortality in patient swith Covid-19.J Thromb Haemost. 2020 Jun;18(6):1324-9.

13. Tabatabai A, Rabin J, Menaker J, Madathil R, Galvagno S, Menne A, et al. Factor VIII and Functional Protein C Activity in CriticallyI ll Patients With Coronavirus Disease 2019: A Case Series. A A Pract. 2020 May;14(7):e01236.

14. Qin C, Zhou L, Hu Z, et al. Dysregulation of immune response in patients with COVID-19 in Wuhan, China. Clin Infect Dis. 2020. DOI:10.1093/cid/ciaa248)

15. Yang X, Yu Y, Xu J, et al. Clinical course and outcomes of critically ill patients with SARSCoV-2 pneumonia in Wuhan, China: a single-centered, retrospective, observational study. Lancet Respir Med. 2020;8(5):475-481.

16. Henry BM, de Oliveira MHS, Benoit S, et al. Hematologic, biochemical and immune biomarker abnormalities associated with severe illness and mortality in coronavirus disease 2019 (COVID-19): a meta-analysis. Clin Chem Lab Med. 2020.

17. Lippi G, Plebani M, Henry BM. Thrombocytopenia is associated with severe coronavirus disease 2019 (COVID-19) infections: A meta-analysis. Clin Chim Acta 2020;506:145-8.

18. Yang X, Yang $Q$, Wang $Y, W u Y, X u$ J, Yu Y, et al. Thrombocytopenia and its association with mortality in patients with COVID-19. J ThrombHaemost 2020;18:1469-72. 